\title{
Improved rapid methods for the determination of iron content and binding capacity of serum
}

\author{
R. N. BEALE, J. O. BOSTROM, AND R. F. TAYLOR \\ From the Institute of Clinical Pathology and Medical Research, \\ Department of Public Health, Sydney, Australia
}

SYNOPSIS Improved methods are described for the determination of serum iron (SeFe) and latent iron-binding capacity under controlled conditions of $p \mathrm{H}$. As before, no precipitation or heating of the serum is required, and controls are not used. Unbuffered sulphonated bathophenanthroline is employed for colour development. Statistical data for 40 normals are presented and comparisons with other data are given; the effects of ageing of serum are studied.

Recently (Beale, Bostrom, and Taylor, 1961) we described direct methods for determining the serum iron and latent iron-binding capacity of serum (referred to hereafter as methods I and II, respectively) in which we obtained normal mean values which were somewhat lower than the grand mean of other workers. Since then, we have attempted to improve both methods by investigating the effect of $p \mathrm{H}$ on iron extraction by acid buffers, and on iron uptake by serum. As a result, two new methods, method III for serum iron and method IV for latent iron-binding capacity, have been evolved which give mean normal values in good accord with the means of other workers. As before, facility and speed of operation have been a chief consideration, together with economy of serum and materials.

\section{GENERAL INITIAL CONSIDERATIONS}

It is known from the work of Surgenor, Koechlin, and Strong (1949) and Laurell (1952) and others that the iron-transferrin complex is stable at about $p \mathrm{H} 7$ and completely dissociated at $p \mathrm{H}$ values below about 4 units. Determinations of serum iron levels were made therefore by dissociation at $p \mathrm{H}$ values within the range 1.5 to 4.5 units. Initially dilute hydrochloric acid-ascorbic acid was used as a serum diluent, but eventually a buffered glycine of $p \mathrm{H} 1.9$ was found suitable, without further subsequent $p \mathrm{H}$ adjustment. The final $p \mathrm{H}$ of sera thus diluted was found to be around $2 \cdot 8$ units. Attempts to adjust the $p \mathrm{H}$ up to values over 3 units resulted in separation of small quantities of fibrous protein. With the buffer mentioned, however, the serum showed no increased turbidity due to the reagent and gave medium suitable for colorimetry. Fortunately, the iron-bathophenanthroline complex is undissociate at about $p \mathrm{H} 2 \cdot 8$, although colour development is slightly slower than at somewhat higher $p \mathrm{H}$ valueso but still sufficiently rapid to prove a practicable proposition.

As regards latent iron-binding capacity detero minations, studies were carried out in order t $\Theta$ determine the optimum $p \mathrm{H}$ of iron uptake by serun $\overrightarrow{\overrightarrow{\mathbb{B}}}$ transferrin. The latent iron-binding capacities of $\overrightarrow{\vec{\alpha}}$ number of sera were determined using buffers in the range $p \mathrm{H} 6 \cdot 1$ to $7 \cdot 8$ (final $p \mathrm{Hs}$ in the range 6.2 to $7 \cdot 7$ units). As expected (see Surgenor et al., 1949 Fig. 2) plotting the latent iron-binding capacity as ordinate against $p \mathrm{H}$ as abscissa shows an increasing binding capacity up to about $p \mathrm{H} 6.95$; but above this, whereas Surgenor's curve for the absorbance at $465 \mathrm{~m} \mu$ of fractionated transferrin solution apo parently reaches a plateau at about $p H 6.5$, ou curve for latent iron-binding capacity of any serum goes through a maximum at about $p \mathrm{H} 6.95$ (Table 离

TABLE I

LATENT IRON-BINDING CAPACITY VALUES AT VARYING $p$ HS FOR TWO NORMAL SERA EXPRESSED AS A PERCENTAGE THE MAXIMUM VALUE

\begin{tabular}{|c|c|c|}
\hline$p \mathbf{H}$ & Serum 1 & Serum 2 \\
\hline $\begin{array}{l}7 \cdot 1 \\
7 \cdot 05 \\
7 \cdot 0 \\
6 \cdot 95 \\
6.9 \\
6 \cdot 8 \\
6.7 \\
6.6\end{array}$ & $\begin{array}{c}89 \cdot 7 \\
92.4 \\
97 \cdot 8 \\
100 \\
98 \cdot 7 \\
89 \cdot 3 \\
74.1 \\
56.2\end{array}$ & $\begin{array}{c}- \\
86.9 \\
93.4 \\
98.4 \\
100 \\
93.4 \\
77.6 \\
58.5\end{array}$ \\
\hline
\end{tabular}




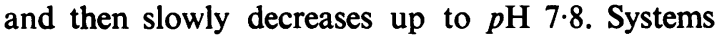
more alkaline than this were not investigated. The reason for this maximum is not clear. A possibility would be to regard the iron-transferrin complex simply as most stable at about $p \mathrm{H} \mathrm{6.95}$, although Laurell (1952) states that it is stable in the range $p \mathrm{H} 7$ to 10. Furthermore, Surgenor's curve shows no drop in value above $p \mathrm{H} 7$, although his curve stops at $p \mathrm{H} 7 \cdot 1$, confirming Laurell's statement.

With these considerations in mind, we concluded that a fairly narrow $p \mathrm{H}$ range of $6.93 \pm 0.05$ is desirable for reproducible measurement and comparison of latent iron-binding capacity values, particularly as this range gives maximum uptake of iron by any serum, with minimal changes in latent iron-binding capacity values with increasing age of the serum.

Control of $p \mathrm{H}$ was achieved by the use of a trismaleate-ascorbic acid buffer of $p \mathrm{H} 6 \cdot 85$, giving final $p \mathrm{H}$ values within the prescribed range.

METHOD III:

THE DIRECT DETERMINATION OF SERUM IRON

Morning blood specimens were collected and glassware was prepared as previously described.

REAGENTS The following were prepared:-

Glycine buffer $p \mathrm{H} 1.9$ Prepare $0.2 \mathrm{M}$ glycine by dissolving $1.50 \mathrm{~g}$. glycine A.R. in iron-free water and diluting to $100 \mathrm{ml}$. To make the buffer, take $12.5 \mathrm{ml} .0 .2 \mathrm{M}$ glycine, $2.6 \mathrm{ml}$. M hydrochloric acid and dilute to $50 \mathrm{ml}$. with water. Adjust to $p \mathrm{H} 1.88$ to 1.92 . To a $20 \mathrm{ml}$. portion of this add about $5 \mathrm{mg}$. ascorbic acid. This is ready for use at this stage.

Bathophenanthroline sulphonate reagent $0.4 \%$ To $200 \mathrm{mg}$. bathophenanthroline in a hard glass boiling tube add $1 \mathrm{ml}$. chlorsulphonic acid and boil the contents gently over a micro-flame for 30 seconds. Cool the tube to room temperature and cautiously add $10 \mathrm{ml}$. water. Add $6.3 \mathrm{ml}$. $5 \mathrm{M}$ sodium hydroxide and heat for about five minutes in a water bath at $100^{\circ}$ until the solid has dissolved. Cool to room temperature, dilute to $45 \mathrm{ml}$., and adjust the $p \mathrm{H}$ with dilute hydrochloric acid to about 6.7 units. The solution is practically unbuffered so that time should be allowed for drift in the $p \mathrm{H}$ meter reading. Dilute to $50 \mathrm{ml}$., mix, and refrigerate until the following day. Filter, add a few drops of chloroform, and store in the refrigerator. The reagent is a modification of that described by Trinder (1956).

Standard iron $25 \mu \mathrm{g} . \mathrm{Fe} / \mathrm{ml}$. This is prepared as described previously. The keeping qualities are good; the reagent has been found to be stable at room temperatures for at least three months.

PROCEDURE The $1 \mathrm{~cm}$. optical cells are prepared as previously described. Into cell B (for blank) measure $0.5 \mathrm{ml}$. water and into cell $\mathrm{T}$ (for test) $0.5 \mathrm{ml}$. serum. To each add $2.0 \mathrm{ml}$. prepared buffer and mix with a glass rod flanged at the bottom. After two minutes read $T$ against B at $534 \mathrm{~m} \mu$. To T and B add $0.08 \mathrm{ml}$. bathophenanthroline reagent by means of a $0.2 \mathrm{ml}$. graduated pipette; then mix. After five minutes (to allow for somewhat slower colour development in the blank), or as soon as a stable reading is achieved, read again at 534 $\mathrm{m} \mu$. To $\mathrm{T}$ only add $0.04 \mathrm{ml}$. standard iron reagent $(1 \mu \mathrm{g}$. Fe), mix, and after one minute re-read $\mathrm{T}$ against $\mathrm{B}$. Avoid moving the cells from their holder throughout the procedure.

CALCULATION This is precisely the same as for method I.

\section{METHOD IV: \\ THE DIRECT DETERMINATION OF LATENT IRON-BINDING CAPACITY}

REAGENTS These are as for method II, the salineascorbic acid being replaced by:

Tris-maleate buffer $p \mathrm{H} \quad 6.9$ Tris (hydroxymethyl)aminomethane, $1.21 \mathrm{~g}$., $1.16 \mathrm{~g}$. maleic acid (or $0.98 \mathrm{~g}$. maleic anhydride), and $9.3 \mathrm{ml}$. $\mathrm{M}$ sodium hydroxide are mixed, dissolved in water, and the whole diluted to $200 \mathrm{ml}$. Adjust to $p \mathrm{H} 6.9$ if necessary and preserve with chloroform. Before use adjust an aliquot to $p \mathrm{H} 6.85$ by the addition of small quantities of ascorbic acid; use a $p \mathrm{H}$ meter standardized with an accurate phosphate buffer. The tris-maleate buffer is usually low in iron content (B.D.H. materials).

PROCEDURE Into cell B measure $0.58 \mathrm{ml}$. water and into $\mathrm{T}, 0.5 \mathrm{ml}$. serum, and to both add $2 \mathrm{ml}$. tris-maleate buffer, $p \mathrm{H} 6.85$. To $\mathrm{T}$ only add $0.08 \mathrm{ml}$. $(2 \mu \mathrm{g}$.) standard iron and mix the contents of both cells. In some cases of iron-deficiency anaemia this has to be increased to $0.16 \mathrm{ml}$. $(4 \mu \mathrm{g}$.) iron. After two minutes read as before at $534 \mathrm{~m} \mu$. To each cell add $0.08 \mathrm{ml}$. bathophenanthroline reagent and after 10 minutes (or when equilibrium is attained) read $\mathrm{T}$ against B. Finally add $0.04 \mathrm{ml} .(1 \mu \mathrm{g}$.) standard iron to T only. Mix, and after one minute read as before.

Calculation This is identical with that for method II.

\section{RESULTS}

STATISTICAL ANALYSIS OF NORMAL RANGES FOR MALE AND FEMALE BLOOD DONORS Blood samples from 20 male and 20 female donors with normal haemoglobin levels were collected as described previously. In no case had more than three previous donations been made, the average being 1.3 donations. No correlation could be found between the number of donations (up to 3) and the serum iron or total iron-binding capacity values. The sera were separated as soon as possible after collection of the specimens ( $\sim$ three hours), which in all cases took place in the middle of the morning, and the analyses were then carried out immediately. According to Laurell (1952) most published data are on morning specimens, so that differences due to diurnal variation which do 
apparently exist should be minimized when comparisons of data are made. Another factor which has not been considered in any great detail in the present work is the variation in mean serum iron levels with the age of the subject; the work of Pirrie (1952) has shown this variation to be quite appreciable for both sexes. Pirrie points out that when he selects individuals in the 16 to 40 age range his results are in very good accord with previously published data. If he includes all his individuals in the 10-80 years range, his mean age is higher, and weighted in favour of the lower iron levels in older people. His means for serum iron are then $23 \mu \mathrm{g}$. \% lower for males and $20 \mu \mathrm{g}$. $\%$ lower for females. The age range of our present series is 18 to 47 years and it should therefore be fairly comparable with the other published data. For example, Davies, Levin, and Oberholzer's (1952) normals ranged from 18 to 45 years and their means and ours are both in good accord with the grand means considered in this work.

The following statistics were used:-

\section{(a) For normal ranges}

$\overline{\mathrm{x}}=$ mean value of population sample $\sigma=$ standard deviation for a large population $x \pm 1.96 \sigma=$ range including $95 \%$ all normal values $\mathrm{n}=$ number of individuals in sample

(b) For precision of methods (duplicate determinass

(Standard error of measurement) ${ }^{\mathbf{2}}$ (S.E.M.) $=\frac{\Sigma_{\triangle}{ }^{2}}{2 \mathrm{~N}}$ where $\triangle=$ difference between the values of duplicat determinations as a percentage of the mean of the pair

$\mathbf{N}=$ number of pairs of determinations made

Table II summarizes the results obtained be methods III and IV, the means being compared with the grand means calculated from the data of the authors quoted by Davies et al. (1952) together with Davies's and our data. (The clinically more significant total iron-binding capacity values are given, ratheos than the latent iron-binding capacities.)

The results summarized in Table II indicate satisfactory agreement between our mean values and the grand means.

The normal $( \pm 1.96 \sigma)$ ranges for $95 \%$ of alf individuals are thus as shown below (Table III); the figures are compared with those of Laurell (1947) who has examined one of the largest series so fap recorded (61 males and 39 females).

TABLE II

COMPARISON OF DATA FROM PRESENT METHODS WITH GRAND UNWEIGHTED ${ }^{1}$ MEAN VALUES OF SOME PUBLISHED DATA (DAVIES et al., 1952)

\begin{tabular}{|c|c|c|c|c|}
\hline \multirow[t]{2}{*}{ Determination } & \multicolumn{2}{|l|}{ Males } & \multicolumn{2}{|l|}{ Females } \\
\hline & All Workers & Present & All Workers & Present \\
\hline Serum iron $(\mu \mathrm{g} . \%)$ & 120 & $\begin{array}{l}\overline{\mathrm{x}}=116 \\
\sigma= \pm 29 \\
\mathrm{n}=20\end{array}$ & 107 & $\begin{array}{l}\overline{\mathbf{x}}=107 \\
\sigma= \pm 31 \\
\mathrm{n}=20\end{array}$ \\
\hline Total iron-binding capacity ( $\mu \mathrm{g} . \%$ ) & 320 & $\begin{array}{l}\overline{\mathbf{x}}=322 \\
\sigma= \pm 29 \cdot 5 \\
\mathbf{n}=20\end{array}$ & 323 & $\begin{array}{l}\dot{x}=322 \\
\sigma= \pm 27 \cdot 5 \\
\mathbf{n}=20\end{array}$ \\
\hline$\%$ saturation & $37 \cdot 5$ & $\begin{array}{l}\bar{x}=35.9 \\
\sigma= \pm 8.0 \\
n=20\end{array}$ & $33 \cdot 3$ & $\begin{array}{l}\overline{\mathbf{x}}=33.3 \\
\sigma= \pm 9.0 \\
\mathrm{n}=20\end{array}$ \\
\hline
\end{tabular}

'The weighted means (allowing for number of normals investigated by each worker) do not differ significantly from the means given here.

TABLE III

NORMAL RANGES AND MEANS

\begin{tabular}{|c|c|c|c|c|}
\hline \multirow[t]{2}{*}{ Determination } & \multicolumn{2}{|l|}{ Males } & \multicolumn{2}{|l|}{ Females } \\
\hline & Present & Laurell (1947) & Present & Laurell (1947) \\
\hline Serum iron $(\mu \mathrm{g} . \%)$ & $\begin{array}{c}59-173 \\
116\end{array}$ & $\begin{array}{c}70-214 \\
124\end{array}$ & $\begin{array}{c}46-168 \\
107\end{array}$ & $\begin{array}{c}57-196 \\
108\end{array}$ \\
\hline Total iron-binding capacity ( $\mu \mathrm{g} . \%)$ & $\begin{array}{c}264-380 \\
322\end{array}$ & $\begin{array}{c}254-406 \\
315\end{array}$ & $\begin{array}{c}268-376 \\
322\end{array}$ & $\begin{array}{c}245-395 \\
315\end{array}$ \\
\hline$\%$ saturation & $\begin{array}{c}20 \cdot 2 \cdot 51 \cdot 6 \\
35 \cdot 9\end{array}$ & $\begin{array}{c}21 \cdot 0-81 \cdot 1 \\
39 \cdot 4\end{array}$ & $\begin{array}{c}15 \cdot 7-50 \cdot 9 \\
33 \cdot 3\end{array}$ & $\begin{array}{c}14 \cdot 4-66 \cdot 0 \\
34 \cdot 5\end{array}$ \\
\hline
\end{tabular}

Males 
The general agreement is again satisfactory on the whole, particularly as regards total iron-binding capacity values. Both sets of data show clearly that the average normal serum iron level for females is lower than for males, but that the average transferrin concentration is the same for both sexes.

STANDARD ERRORS OF MEASUREMENT These were:

For serum iron, S.E.M. $= \pm 2 \cdot 3 \%$ (for 18 pairs of duplicates) and for latent iron-binding capacity, S.E.M. $= \pm 1.9 \%$ (for 12 pairs) which give, for serum iron values, $95 \%$ confidence limits of $\pm 4.5 \%$; and for latent iron-binding capacity values, limits of $\pm 3.7 \%$; that is, for example, the probability of the measured serum iron value being more than $\pm 4.5 \%$ from the 'true' value is 1 in 20.

STUDENT's $t$ TEST Student's test was applied to various pairs of methods for serum iron and showed that for males there was no significant difference between methods I and III and for females the difference was just significant. Similar comparisons of methods II and IV for latent iron-binding capacities showed a difference for males which was just significant and for females quite significant $(t=5 \cdot 17$; for 30 degrees of freedom, $t=2.04$ at the $5 \%$ level). It must be concluded from this evidence that method I gave serum iron values which were slightly low, particularly for normal women, and that method II gave decidedly low values for normals of both sexes.

Comparison of serum irons by method III with a hydrochloric acid-trichloracetic acid precipitation method (Kok and Wild, 1960, modified) showed no significant difference between the methods. The standard error of measurement for the precipitation method was $\pm 6.7 \%$, about three times that of method III.

EFFECTS OF AGEING OF THE SERUM AT ROOM TEMPERATURE Sera were kept in specially cleaned, capped polythene vials at room temperature for up to 144 hours and the values determined at various time intervals, counting from the time of collection of blood specimens. Refrigeration and storage at low temperatures were not investigated, since the varying amounts of turbidity and precipitation frequently encountered on cooling or freezing serum would interfere with optical measurements by the methods described. Freezing or cooling furthermore represents a wider departure from physiological conditions.

Storage at room temperature for a week appeared not to have any visible effect on the sera apart from the development of a very slight turbidity in a few specimens. However, analysis after various time intervals showed that small physical changes must occur in the transferrin molecules on ageing at about $25^{\circ} \mathrm{C}$. The changes (averaged over a number of sera) which took place after $n$ hours are shown in Table IV.

A small initial drop in values followed by a marked rise at 72 hours indicates that from the analytical point of view sera may be examined up to about 60 hours with barely significant changes in values.

\section{TABLE IV}

AVERAGE CHANGES IN SERUM IRON, LATENT AND TOTAL IRON-BINDING CAPACITY, WITH TIME

\begin{tabular}{cccc}
$n$ Hours & $\begin{array}{l}\text { Serum Iron } \\
(\%)\end{array}$ & $\begin{array}{l}\text { Latent Iron- } \\
\text { binding Capacity } \\
(\%)\end{array}$ & $\begin{array}{l}\text { Total Iron- } \\
\text { binding Capacity } \\
(\%)\end{array}$ \\
\hline 0 & 0 & 0 & 0 \\
24 & -1 & -2 & -3.5 \\
48 & -1 & -1 & -1 \\
72 & +5 & +4.5 & +4 \\
96 & +6 & +7.5 & +8 \\
144 & +6 & +8 & +8.5
\end{tabular}

Beyond this time small positive errors will occur on average but these may be corrected for approximately if the age of the serum is known. Beyond 96 hours little further change in levels is observed. No significant difference in behaviour between male and female sera was observed.

\section{DISCUSSION}

When control of $p \mathrm{H}$ is introduced, and appropriate $p \mathrm{H}$ values are employed for the determinations of serum iron and latent iron-binding capacity, it is possible, by direct measurements, to obtain mean values and ranges in good agreement with published data. Our previously reported values tended to be too low since insufficient account was taken of the importance of $p \mathrm{H}$ as a variable, particularly in the determination of serum latent iron-binding capacity. Further, as is now evident, undue confidence in the previous results followed from the apparently gratifying recoveries which were obtained in both methods. In the present study, recovery experiments were not carried out exhaustively, but for the few sera which were examined virtually quantitative recoveries were obtained once more. It would appear therefore that iron added in vitro is bound, at least initially over short periods, less firmly than in vivo and is fully recoverable. This highlights once again the dangers inherent in over-reliance on recovery experiments.

The ageing effects described above indicate that there are different sites of iron binding in the transferrin. The reason for the slight but just significant drop in values up to 48 hours is not clear, but could be associated with temporarily collapsed coils in the 
transferrin molecular structure with some iron centres less available. The increasing values with further ageing could then be interpreted as a slow denaturation with an opening out of the protein helix rendering deeper centres of iron binding available both for the removal of bound iron from, and for the addition of added iron to, vacant centres.

As before, in the determination of latent ironbinding capacity, it was found that some time was required to equilibrate the added iron with the serum, the absorbance of the iron complex gradually increasing over a period of about 10 minutes. An initial binding with less specific centres in the transferrin, or in some other serum constituent is therefore indicated, this binding being weak in character. This non-specific binding may be demonstrated by the addition of larger quantities of iron to the serum. The time required to reach equilibrium is then very much protracted. For this reason the amount of iron added in method IV is kept to a minimum, so as to ensure only a moderate excess of free iron before the addition of bathophenanthroline reagent.

As before, a spectrophotometric study of the absorption curves at each stage of both methods was made and no significant changes in background absorption, due to variable effects of the reagents on the serum, were noted. Duplicate runs on the same serum gave sets of curves in very good accord. For this reason, no controls are necessary as a general rule. (A reagent blank for latent iron-binding capacity analyses may be included if desired, since any ionic iron in the reagents would be taken up to the serum and lead to a lowered value.) The reagent blank is usually less than a latent iron-binding capacity equivalent of $10 \mu \mathrm{g}$. \% for good quality A.R. materials but may become important for low values of latent iron-binding capacity.

Since beginning this work our attention was drawn to the methods of Schade, Oyama, Reinhart, and Miller (1954), who use a direct method without protein precipitation, the iron being liberated from the serum at $p \mathrm{H} 6$ by means of a high concentration of phosphate ions; incubation at $45^{\circ}$ for 20 minutes is employed. Latent iron-binding capacity levels are $\stackrel{0}{\vec{乛}}$ determined by adding excess iron and tris buffer at pH 8.5 together with Elon as reducing agent. Incubation is again used for equilibration. Control sera are used throughout. Using Schade's techniques, $\frac{}{-}$ Zizza and Block (1961) obtain a mean serum iron $\overline{\bar{c}}$ for 10 males of 150 (range 110-170) $\mu \mathrm{g}$. \% and for five females a mean of 120 (range 78 to 170 ) $\mu \mathrm{g} . \%$. Their values for males are stated to be lower thanes those of Schade, which they quote as 170 (range $112 \vec{\circ}$ to 225$) \mu \mathrm{g}$. \%. These means are all somewhat higherthan those found by most workers.

Comparison of our previous mean values for serum iron with the present ones shows that while for males no significant difference occurs $(109 \mu \mathrm{g}$. $\%$ as against $116 \mu \mathrm{g} . \%$ ), for females there is a marked difference between the mean dithionite-extractables iron and the dissociable iron $(82 \mu \mathrm{g}$. \% as agains 5 $107 \mu \mathrm{g} . \%$ ). This might indicate that some of the iron? in the sera of at least some females is bound in different fashion and more firmly complexed than that in males. Further work is necessary, using bothf methods I and III for analysis of each of a number of sera, in order to confirm or refute this possibility

Once again we wish to thank members of the staff of the Red Cross Blood Transfusion Service, Sydney, for theis cooperation in supplying unhaemolysed blood specimens We are indebted to Mr. Cho of this Institute for hi\$ assistance in the transport of specimens.

Approval for the publication of this paper has been given by the Director of State Health Services, Nev? South Wales Department of Public Health.

\section{REFERENCES}

Beale, R. N., Bostrom, J. O., and Taylor, R. F. (1961). J. clin. Path? $14,488$.

Davies, G. Levin, B., and Oberholzer, V. G. (1952). Ibid., 5, 312. Kok, D'A., and Wild, F. (1960). Ibid., 13, 241.

Laurell, C. B. (1947), Acta physiol. scand., 14, Suppl. 46. - (1952) Pharmacol. Rev. 4, 371.

Pirrie, R. (1952). J. clin. Path., 5, 10.

Schade, A. L., Oyama, J., Reinhart, R. W., and Miller, J. R. (1954)음 Proc. Soc. exp. Bi.jl. (N.Y.), 87, 443.

Surgenor, D. M., Koechlin, B. A., and Strong, L. E. (1949). J. clin Invest., 28, 73.

Trinder, P. (1956). J. clin. Path., 9, 170.

Zizza, F., and Block, M. (1961). Acta haemat. (Basel), 25, 1. 